(BJ2008/0608)

\title{
Two biochemically distinct and tissue-specific twinfilin isoforms are generated from mouse twinfilin-2 gene by alternative promoter usage
}

Elisa M. Nevalainen*, Aneta Skwarek-Maruszewska*, Attila Braun $\dagger$, Markus Moser $\dagger$, Pekka Lappalainen*1

*Institute of Biotechnology, P.O. Box 56, 00014 University of Helsinki, Finland, $\dagger$ Max Planck Institute of Biochemistry, Department of Molecular Medicine, Am Klopferspitz 18, D-82152, Martinsried, Germany

${ }^{1}$ Corresponding author: Dr. Pekka Lappalainen, Institute of Biotechnology, P.O. Box 56, 00014 University of Helsinki, Finland

Phone: +358-9-19159499

Fax: +358-9-19159366

Email: pekka.lappalainen@ helsinki.fi 


\begin{abstract}
Twinfilin is an evolutionarily conserved regulator of actin dynamics composed of two actin-depolymerizing factor homology (ADF-H) domains. Twinfilin binds actin monomers and heterodimeric capping protein with high affinity. Previous studies demonstrated that mammals express two twinfilin isoforms, twinfilin-1 and twinfilin-2, of which at least twinfilin-1 also regulates cytoskeletal dynamics by capping actin filament barbed ends. Here, we show that alternative promoter usage of the mouse twinfilin-2 gene generates two isoforms, which differ from each other only at their very $\mathbf{N}$-terminal region. Of these isoforms, twinfilin-2a is predominantly expressed in non-muscle tissues, whereas expression of twinfilin$\mathrm{2b}$ is restricted to heart and skeletal muscle. Both proteins bind actin monomers and capping protein, as well as efficiently cap actin filament barbed ends. However, the N-terminal ADF-H domain of twinfilin-2b interacts with ADP-Gactin with five-fold higher affinity than with ATP-G-actin, whereas the corresponding domain of twinfilin-2a binds ADP-G-actin and ATP-G-actin with equal affinities. Together, these data show that, like twinfilin-1, mouse twinfilin-2 is a filament barbed end capping protein, and that two tissue-specific and biochemically distinct isoforms are generated from the twinfilin-2 gene through alternative promoter usage.
\end{abstract}

Key words: Twinfilin, actin dynamics, cytoskeleton, isoform 


\section{INTRODUCTION}

The actin cytoskeleton plays an essential role in numerous cell biological processes, including motility, cell division, polarized growth, cytokinesis, endocytosis, and signal transduction. The structure and dynamics of the actin cytoskeleton are both spatially and temporally regulated by a large number of actin-binding proteins, which interact with filamentous and/or monomeric actin [reviewed in 1 and 2].

Twinfilin is an evolutionarily conserved multifunctional actin-binding protein, which is involved in the regulation of motile and morphological processes in organisms from yeasts to mammals [3-8]. Twinfilin forms a stable, high affinity complex with ADPactin monomers, decreases the rate of nucleotide exchange on actin monomers and prevents their assembly to filament ends $[9,10]$. Interaction between twinfilin and Gactin can be down-regulated by phosphatidylinositol 4,5-bisphosphate (PIP2) at least in vitro [10]. Twinfilin also interacts with the heterodimeric capping protein, and at least in budding yeast this interaction is necessary for twinfilin's correct sub-cellular localization to the cortical actin cytoskeleton [10-12]. In addition, recent studies revealed that mouse twinfilin-1 caps filament barbed ends with a preferential affinity to ADP-bound filament ends. This activity appears to be essential for the role of twinfilin-1 in motile processes [6]. Furthermore, yeast twinfilin was shown to induce filament severing at low $\mathrm{pH}$ and this activity is inhibited by binding to heterodimeric capping protein [13].

Twinfilins are composed of two actin-depolymerizing factor homology (ADF-H) domains separated by a short linker and followed by a 35-residue C-terminal tail region [14]. The two ADF-H domains are $20 \%$ homologous to ADF/cofilins and to each other [15]. Studies on mouse twinfilin-1 revealed that the high-affinity actin monomer-binding site is located in the C-terminal ADF-H domain, whereas the presence of both ADF-H domains is required for filament barbed end capping $[9,16]$. The capping protein binding site is located in the C-terminal tail region in yeast twinfilin and in mouse twinfilin-1 [12].

Yeasts, worms, and flies have only one twinfilin isoform. In mammals, however, two twinfilin genes (twinfilin-1 and twinfilin-2) exist. Twinfilin-1 and twinfilin-2 proteins 
share $\sim 75 \%$ identity. Both mouse twinfilin isoforms bind actin monomers and capping protein with high affinity, but show different tissue distributions. Twinfilin-1 is the major isoform in the developing embryo and in most adult mouse non-muscle tissues, whereas twinfilin-2 expression is most abundant in heart, skeletal muscle, and spleen [11].

Here we show that the mouse twinfilin-2 gene encodes for two different twinfilin-2 isoforms (designated twinfilin-2a and twinfilin-2b) that are generated by alternative promoter usage. The two twinfilin-2 variants differ only in the very $\mathrm{N}$-terminal region and are identical to each other from twinfilin-2a residue 9 and twinfilin-2b residue 7 onwards. Our results show that twinfilin-2a and twinfilin-2b display distinct tissuespecific expression patterns and differ from each other in respect to interaction with actin monomers. Together, these data suggest that alternative promoter usage of the twinfilin-2 gene generates two biochemically distinct twinfilin isoforms that fulfil specific needs for regulation of actin dynamics in specialized mammalian cell-types.

\section{MATERIALS AND METHODS}

\section{Plasmid construction}

Plasmids for twinfilin-1 and twinfilin-2a expression (pPL144 and pPL182, respectively) as a His-tagged fusion protein in Escherichia coli have been described earlier $[11,17]$. The DNA fragments corresponding to full-length mouse twinfilin-2b as well as to twinfilin-2a N-terminal domain (residues 1-142), twinfilin-2b N-terminal domain (residues 1-140) and twinfilin-2 C-terminal domain (residues 169-316 in twinfilin-2a and 167-314 in twinfilin-2b) were amplified by PCR from pPL182 plasmid. The oligonucleotides introduced NcoI and HindIII sites at the 5' and 3' ends of the PCR products, respectively. The PCR fragments were digested with NcoI and HindIII and ligated into the pHAT2 [18] vector to create plasmids pPL481, pPL482, pPL483 and pPL484. The plasmid for expressing mouse $\alpha 1 \beta 2$ capping protein in $E$. coli has been described previously [10]. Generation of the plasmid for expressing myctagged twinfilin-1 in mammalian cells (pPL79) was described earlier [17]. For generation of the constructs for expressing myc-tagged twinfilin-2a and twinfilin-2b, the corresponding cDNA fragments were amplified by PCR. The oligonucleotides 
introduced EcoRV and HindIII sites at the 5' and 3' ends of the PCR products, respectively. The PCR fragments were digested with EcoRV and HindIII and ligated into the myc-tagged pEGFP-N1 based vector (Clonetech) to create plasmids pPL80 and pPL554, respectively.

\section{Protein purification}

The expression and purification of full-length mouse twinfilin-1, twinfilin-2a, and twinfilin-2b and the individual domains of twinfilin- $2 a$ and twinfilin- $2 b$ as his-tagged proteins were carried out as previously described [11]. Mouse $\alpha 1 \beta 2$-capping protein was purified as previously described [10]. Actin was purified from rabbit skeletal muscles [19] and labelled by NBD-Cl [20, 21] and pyrenyl as described [22, 23]. Recombinant human gelsolin was obtained from Cytoskeleton Inc. Spectrin-actin seeds were isolated from human erythrocytes as described [24].

\section{RNA extraction}

Total RNA was isolated from various mouse tissues by TRIzol (Invitrogen) according to the manufacturer's protocol. Briefly, tissue samples were homogenized in a $15 \mathrm{ml}$ tube with Polytron (Glen Mills) in $1.0 \mathrm{ml}$ of TRIzol per $100 \mathrm{mg}$ of tissue. Homogenates were incubated $10 \mathrm{~min}$ at room temperature and centrifuged at $12,000 \times \mathrm{g}$ for $15 \mathrm{~min}$ at $4^{\circ} \mathrm{C}$ to pellet insoluble material and high-molecular-weight DNA. Chloroform was added, tubes were shaken for 15 seconds, incubated 3 min at room temperature and centrifuged at $12,000 \times \mathrm{g}$ for $15 \mathrm{~min}$ at $4^{\circ} \mathrm{C}$. After phase separation, RNA was precipitated with isopropanol, washed with $75 \%$ ethanol and resuspended in an appropriate volume of DEPC-treated water. RNA purity and quantity was ascertained from optical density at 260 and $280 \mathrm{~nm}$. The samples were stored at $-80^{\circ} \mathrm{C}$ until use.

\section{Real-time quantitative PCR}

Three micrograms of total RNA was reverse-transcribed at $42^{\circ} \mathrm{C}$ for $1 \mathrm{~h}$ in $20 \mu \mathrm{l}$ solution containing 200 units of SuperScript II Reverse Transcriptase (Invitrogen) and $500 \mathrm{ng}$ of Oligo(dT). The resulting cDNA was either immediately used for nonquantitative RT-PCR or quantitative PCR (Q-PCR) or stored at $-20^{\circ} \mathrm{C}$ until use. QPCR was applied to determine the expression levels of each isoform in different 
tissues. Q-PCR reactions were carried out on a LightCycler 480 System (Roche) by using the SYBR Green I Master kit (Roche). Reactions had a final volume of $20 \mu 1$ and contained 4 pmol of each primer and $0.4 \mu \mathrm{l}$ of cDNA obtained by reverse transcription. Q-PCR was performed with the following temperature conditions: $95^{\circ} \mathrm{C}$ for $5 \mathrm{~min}$ and 40 cycles at $95^{\circ} \mathrm{C}$ for $10 \mathrm{~s}, 58^{\circ} \mathrm{C}$ for $15 \mathrm{~s}$ and $72^{\circ} \mathrm{C}$ for $15 \mathrm{~s}$. Primers designed for specific detection of different twinfilin isoforms and GAPDH are listed in Table 1. All primer pairs resulted in a $\sim 100$ bp product. The amplification of the twinfilin- 1 cDNA was performed using primers ES110 and ES121, twinfilin-2a with primers ES122 and ES124, twinfilin-2b with primers ES124 and ES125. GAPDH served as housekeeping gene for the adjustment of relative expression data. The amplification of the GAPDH cDNA was performed using primers ES126 and ES127. To verify the identity of the various PCR products, RT-PCR was performed and the DNA fragments were separated on 2\% agarose gels, extracted by NucleoSpinExtract II Band Extraction Kit (Macherey Nagel) and subjected to sequencing.

\section{Actin monomer binding assay}

Actin monomer binding experiments were performed by monitoring the change in the fluorescence of 7-chloro-4-nitrobenz-2-oxa-1,3-diazole (NBD)-labeled G-actin at different twinfilin concentrations as described earlier [9]. ADP-actin was prepared by incubating NBD-actin with hexokinase-agarose beads (Sigma) and glucose for $2 \mathrm{~h}$ at 4 ${ }^{\circ} \mathrm{C}$ [25]. The final concentration of actin in these assays was $0.2 \mu \mathrm{M}$, and the twinfilin concentrations ranged from 0.05 to $14 \mu \mathrm{M}$. Experiments were carried out at room temperature in F-buffer (2 mM Tris- $\mathrm{HCl}$ ( $\mathrm{pH} 8.0$ ), $0.1 \mathrm{mM} \mathrm{CaCl}_{2}, 0.1 \mathrm{mM}$ DTT, 0.2 $\mathrm{mM}$ ADP or ATP, $1 \mathrm{mg} / \mathrm{ml}$ bovine serum albumin, $2 \mathrm{mM} \mathrm{MgCl}_{2}, 0.1 \mathrm{M} \mathrm{KCl}$ ). The reactions were measured using a BioLogic MOS-250 fluorescence spectrophotometer and the data analyzed as described previously [9].

\section{Actin polymerization assays}

The effect of twinfilin on actin filament assembly kinetics was monitored by the increase in pyrenyl-actin fluorescence in the presence of spectrin- or gelsolin-capped filaments as described earlier [6]. Experiments were carried out with $2.5 \mu \mathrm{M}$ actin (10\% pyrene labeled) and twinfilin concentrations ranging from 0.1 to $12 \mu \mathrm{M}$. The excitation and emission wavelengths were 365 and $407 \mathrm{~nm}$, respectively. 
Polymerization was monitored at room temperature with a BioLogic MOS-250 fluorescence spectrophotometer at 10 second intervals. The initial rate of filament growth was normalized to the value of 1 measured in the absence of twinfilin. The data were analyzed as described previously using the program SigmaPlot 9.0 [6].

\section{Native gel electrophoresis assay}

Interaction of the twinfilin isoforms with capping protein was assayed with $6 \%$ native polyacrylamide gels. Reactions containing $2 \mu \mathrm{M}$ wild-type twinfilin-1, twinfilin-2a or twinfilin-2b or a mutant twinfilin-1 lacking the capping protein binding capacity and 4 $\mu \mathrm{M} \alpha 1 \beta 2$ capping protein in $10 \mathrm{mM}$ Tris ( $\mathrm{pH} 7.5), 50 \mathrm{mM} \mathrm{NaCl}, 0.5 \mathrm{mM}$ DTT were incubated for $60 \mathrm{~min}$ at room temperature. Fifteen $\mu \mathrm{l}$ of the reactions were mixed with $5 \mu$ of loading buffer (125 mM Tris ( $\mathrm{pH} 8.8$ ), $250 \mathrm{mM} \mathrm{NaCl}, 2.5 \mathrm{mM}$ DTT, 50\% glycerol) and loaded onto a 6\% native polyacrylamide gel (Falck et al., 2004). The gel was run at $100 \mathrm{~V}$ for $180 \mathrm{~min}$ using native running buffer $(25 \mathrm{mM}$ Tris, $194 \mathrm{mM}$ glycine $\mathrm{pH} 8.5,0.5 \mathrm{mM}$ DTT), and the proteins were detected by Coomassie Blue staining.

\section{Immunofluorescence microscopy}

Isolation, culturing, transfection and immunofluorescence microscopy of neonatal rat cardiomyocytes was carried out as described previously [39]. The cells were fixed 24 hours after transfection. Endogenous twinfilins were visualized with anti-twinfilin antibody recognizing twinfilin-1 and twinfilin-2 (1:80 dilution), myc-tagged fusion proteins with mouse anti-myc antibody (1:500), and secondary antibodies conjugated to fluorescein or rhodamine (Molecular Probes, Invitrogen). Actin filaments were visualized with alexa 488 or rhodamine-conjugated phalloidin diluted 1:300 (Molecular Probes, Invitrogen) 


\section{RESULTS}

\section{Identification of two twinfilin-2 variants}

A previous study identified two twinfilin isoforms (twinfilin-1 and twinfilin-2) from mammals [11]. To reveal the biological roles of these proteins, we generated twinfilin2 knockout mice. In the knockout construct, the cassette was inserted into the first coding exon of the twinfilin-2 gene. During our analysis of the knockout mice, we noticed that while twinfilin-2 protein and mRNA were absent from all non-muscle tissues examined, twinfilin-2 mRNA and protein were still present in striated muscle and heart (Nevalainen et al., unpublished). Subsequent EST database searches revealed two potential mouse twinfilin-2 variants.

In contrast to the previously identified twinfilin-2 variant [11] (which will be referred to as twinfilin-2a), twinfilin-2b uses an alternative translation initiation codon, which is located 18 nucleotides upstream from the 3" splice acceptor site of the twinfilin-2a intron 1 (Fig. 1A). A TATA box located -20 residues upstream of the translation initiation codon of twinfilin- $2 \mathrm{~b}$ as well as a conserved putative promoter region 5 ' to the TATA box is also present (data not shown). This gives rise to a twinfilin- $2 b$ mRNA that contains an alternative first exon (referred to as exon $2 \mathrm{~b}$ in Fig. 1A) encoding for a twinfilin-2b protein of 347 residues as compared to twinfilin-2a consisting of 349 residues (Fig 1B). Alignment of the amino acid sequences of mouse twinfilin-2a and twinfilin- $2 b$ shows that they are identical to each other with the exception of the $6 / 8$ amino terminal residues.

\section{Tissue-specific expression patterns of twinfilin-2a and twinfilin-2b}

To investigate whether twinfilin-2b mRNA is expressed in vivo and to analyse its expression pattern in comparison to twinfilin-1 and twinfilin-2a, RNA from mouse heart, lung, kidney, spleen, liver, skeletal muscle, and brain was extracted. RNAs were reverse transcribed and the expression of each isoform from these tissues was first examined by a non-quantitative RT-PCR using isoform specific primer pairs (Table 1). Twinfilin-2a was expressed in all tissues examined and twinfilin-1 in all tissues except skeletal muscle. However, based on this experiment, twinfilin-2b expression was 
restricted to heart and skeletal muscles (Fig. 2A). The PCR products were also isolated from an agarose gel and sequenced to verify their identity (data not shown).

The relative amounts of each isoforms were subsequently analysed by Q-PCR (Fig 2B). Q-PCR analysis revealed that twinfilin-2a was expressed in all tissues examined and represents the most abundant isoform in spleen. In contrast, twinfilin-2b expression is restricted to skeletal muscle and heart. Interestingly, twinfilin-2b is the dominant isoform in these tissues at mRNA levels when compared to twinfilin-1 and twinfilin-2a expression. As reported previously [11], twinfilin-1 mRNA was widely expressed in non-muscle tissues, but was absent from skeletal muscle (Fig 2B).

\section{Actin monomer binding properties of twinfilin-2a and twinfilin-2b}

To compare the biochemical properties of the twinfilin isoforms, we produced recombinant mouse twinfilin- $2 \mathrm{a}$ and twinfilin- $2 \mathrm{~b}$ as well as their individual ADF-H domains as His-tagged proteins. All proteins were soluble and monomeric according to their elution position from a gel-filtration column (data not shown). We first examined actin monomer binding of all three twinfilin isoforms under physiological ionic conditions by using a fluorometric assay with NBD-labelled actin monomers. As reported previously for twinfilin-1 and twinfilin-2a [9, 11], also twinfilin-2b binds ADP-G-actin with a significantly (>8-fold) higher affinity than ATP-G-actin (Fig. 3AC). As previously shown for twinfilin-1 [9], the C-terminal ADF-H domain, common to both twinfilin-2 isoforms, binds ADP-G-actin with very high affinity (Fig. 3F).

However, the actin monomer binding properties of the N-terminal ADF-H domains of twinfilin- $2 a$ and twinfilin-2b differed significantly from each other. Whereas the $\mathrm{N}$ terminal ADF-H domains of twinfilin-2a (Fig. 3D) and twinfilin-1 [9] bind ADP-Gactin with a relatively low affinity $\left(\mathrm{K}_{\mathrm{D}} \sim 500-700 \mathrm{nM}\right)$, the corresponding domain of twinfilin-2b bound ADP-G-actin with significantly higher affinity (Fig. 3E). It is also important to note that in contrast to all ADF-H domains examined so far [9, 26-28], the N-terminal ADF-H domain of twinfilin-2a does not show preferential binding to ADP-actin, but instead binds ADP- and ATP-G-actin with equal affinities (Fig. 3D). 


\section{All mouse twinfilins cap actin filament barbed ends}

Recent data showed that, when using mammalian actin, mouse twinfilin- 1 caps actin filament barbed ends, whereas budding yeast and Drosophila melanogaster twinfilins do not display barbed end capping activity [6]. Therefore, we examined whether mouse twinfilin-2a and twinfilin-2b also display filament barbed end capping or if this activity is specific for mammalian twinfilin-1. Barbed and pointed end capping activity was assayed by examining the effects of purified twinfilin- $2 a$ and twinfilin- $2 b$ on the growth of spectrin- or gelsolin-capped actin filaments, respectively. We used mouse twinfilin-1, which inhibits pointed-end growth by sequestration and prevents barbed-end assembly by both sequestering actin monomers and capping filament ends, as a reference in the experiments.

Like twinfilin-1, twinfilin-2a and twinfilin-2b inhibited filament barbed end growth in a range of concentrations substoichiometric to G-actin (Fig. 4A-C). This is not possible by mere sequestering, but is consistent with capping of the barbed ends in addition to sequestration of actin monomers. The pointed end growth was inhibited by sequestering actin monomers only. $\mathrm{K}_{\mathrm{F}}$ values for binding of twinfilin-1, twinfilin-2a and twinfilin-2b to actin filament barbed ends were $0.14 \mu \mathrm{M}, 0.19 \mu \mathrm{M}$, and $0.26 \mu \mathrm{M}$, respectively and $\mathrm{K}_{\mathrm{T}}$ values for $\mathrm{ATP}-\mathrm{G}$-actin sequestration were $0.76 \mu \mathrm{M}, 0.91 \mu \mathrm{M}$, and $0.81 \mu \mathrm{M}$, respectively. These data show that also twinfilin-2a and twinfilin-2b are actin filament barbed end capping proteins.

\section{Twinfilin-2a and twinfilin-2b bind heterodimeric capping protein}

In addition to actin, twinfilin-1 and twinfilin-2a were shown to bind mouse $\alpha 1 \beta 2$ capping protein in vitro [11]. The interaction with heterodimeric capping protein is essential for the correct subcellular localization of twinfilin in budding yeast [10], but the possible biological role of this interaction in mammalian cells is presently not known. Yeast twinfilin does not affect the filament barbed end capping activity of yeast capping protein [12]. However, because mammalian twinfilin-1 and twinfilin-2a also display filament barbed end capping activity [6 and Fig. 4 of this study], their 
possible effects on the barbed end capping activity of heterodimeric capping protein can not be reliably examined.

To examine whether also twinfilin-2b binds capping protein, we performed a native gel electrophoresis assay with purified full-length mouse twinfilins and mouse $\alpha 1 \beta 2-$ capping protein. The capping protein binding site resides in the C-terminal tail of yeast twinfilin and mouse twinfilin-1, and thus a mutant twinfilin-1 construct lacking the Cterminal tail was used as a negative control [12]. Purified capping protein runs as a single band below the migration positions of all full-length twinfilin isoforms on a native polyacrylamide gel (Fig. 5; lane 1). When mixed with each other in a 1:2 molar ratio, a complex of twinfilin and capping protein forms. On a native gel, this complex migrates above the positions of uncomplexed twinfilin and capping protein (Fig. 5; upper band on lane 3), while the band corresponding to the migration position of uncomplexed twinfilin disappears. As expected, the C-terminally deleted twinfilin-1 protein did not display interaction with capping protein (Fig. 5; lanes 4 and 5). However, both twinfilin-2 isoforms interacted with capping protein similar to twinfilin-1 (Fig. 5; lanes 6-9).

\section{Subcellular localizations of twinfilins in rat cardiomyocytes}

In mammalian non-muscle cells, twinfilin-1 and twinfilin-2a show predominantly punctuate cytoplasmic localization that at least in the case of twinfilin-1 partially overlaps with endosomes. In addition, twinfilin-1 localizes to cell-cell contacts and to lamellipodial actin network in cells expressing dominant active forms of Cdc42 and Rac GTPases [6, 11]. To examine the subcellular localizations of twinfilins in muscle cells, we first performed immunofluorescence microscopy on cultured neonatal rat cardiomyocytes by using an antibody that recognizes all three twinfilin isoforms. These cells display regular, contractile myofibrils and thus provide a good model for studying the subcellular localizations of twinfilins in heart cells, where all three isoforms are expressed (see Fig. 2). Immunofluorescence microscopy revealed that twinfilins display predominantly punctuate cytoplasmic staining also in cardiomyocytes, although in some cells endogenous twinfilins also concentrated to myofibrils (Fig. 6A). 
To compare the subcellular localizations of each twinfilin isoform in cardiomyocytes, we expressed $\mathrm{N}$-terminally myc-tagged twinfilin-1, twinfilin-2a and twinfilin-2b in these cells. Similarly to endogenous twinfilin, also the myc-tagged twinfilins displayed mainly punctuate cytoplasmic localizations. Twinfilin- 1 and twinfilin- $2 b$ were also enriched along myofibrils in a subset of cells, whereas in the case of twinfilin-2a significant enrichment to myofibrils was not observed (Fig. 6B). Instead, twinfilin-2a was often concentrated to regions between myofibrils (Fig. 6B and data not shown).

\section{DISCUSSION}

Twinfilin is an evolutionarily conserved protein that regulates actin dynamics in organisms from yeasts to mammals. Mammals have two twinfilin genes that were previously shown to encode biochemically very similar proteins with slightly different expression patterns [11]. Here we demonstrate that a third mammalian twinfilin isoform is produced through alternative promoter usage of the twinfilin-2 gene. Interestingly, the two twinfilin-2 variants display distinct tissue-specific expression patterns, suggesting that promoter usage of twinfilin- 2 is tightly and tissue-specifically regulated. Whereas the expression of twinfilin- $2 b$ is restricted to striated muscle, where it is also the predominant twinfilin isoform, twinfilin-2a is mainly co-expressed with twinfilin-1 in most non-muscle tissues. In cultured cardiomyocytes, twinfilins show mainly punctuates cytoplasmic localization, although that twinfilin-1 and twinfilin- $2 b$ also concentrate to myofibrils.

Similar as described here for twinfilin-2, previous studies showed that the two ADF/cofilin family actin-binding proteins of Caenorhabditis elegans, UNC-60A and UNC-60B, are generated from the $u n c-60$ gene. However, the UNC60A and UNC60B isoforms are generated through alternative splicing instead of alternative promoter usage as shown here for twinfilin-2 [29]. UNC-60A is expressed in various tissues and required for early embryogenesis, whereas UNC-60B is specifically expressed in body wall muscle and is essential for myofibril assembly [30, 31]. Muscle specific isoforms of central actin-regulating proteins are common in mammals. However, they are usually encoded by a separate gene from their corresponding non-muscle specific isoforms, mainly as a result of gene duplications during evolution. These include for 
example muscle-specific ADF/cofilin, cyclase-associated-protein, and $\alpha$-actinins [3236].

In our database searches, we found twinfilin-2b homologues from rat and chicken, suggesting that the alternative promoter usage that produces the two variants of twinfilin-2 is evolutionarily conserved in vertebrates. Furthermore, alternative splicing of chicken twinfilin-2 gene from another position was also recently reported [37]. Interestingly, we did not find the twinfilin-2b variant from human ESTs, suggesting that this specific alternative promoter usage event may have been lost during the evolution of primates.

Our study demonstrates that all three mammalian twinfilin isoforms bind capping protein and cap filament barbed ends in a similar manner. Thus these data provide evidence that actin filament barbed end capping activity is not restricted to twinfilin-1 only, but may be a general feature of all mammalian twinfilins. In addition, all three twinfilins bind actin monomers, but display differences in these interactions. The isolated N-terminal ADF-H domain of twinfilin-2b binds ADP-G-actin with approximately 2,5-fold higher affinity compared to the corresponding domain from twinfilin-2a. However, the N-terminal domain of twinfilin-2a displays $\sim 2$-fold higher affinity to ATP-G-actin than the corresponding twinfilin-2b domain. Consequently, the full-length twinfilin-2a binds ATP-G-actin with higher and ADP-G-actin with lower affinity than twinfilin-2b. These differences in G-actin interactions can be explained by the fact that the N-terminal region, which differs between twinfilin-2a and twinfilin-2b, was shown to play a central role in G-actin binding of twinfilin-1 [38].

In conclusion, we have identified two biochemically distinct variants of twinfilin-2 protein, and show that they are expressed in differentially. Future cell biological and knockout mouse studies are required to elucidate the biological roles of these two twinfilin isoforms and to reveal the possible redundant roles of twinfilin- $2 \mathrm{a}$ and twinfilin-1 in non-muscle tissues. Furthermore, it will be important to examine the role of twinfilin-2b in skeletal and heart muscle cells. 


\section{ACKNOWLEDGMENTS}

We thank Mikko Frilander, Reinhard Fässler, Ville Paavilainen and Martina Serlachius for critical reading of the manuscript. We thank Maria Vartiainen for reagents. This study was supported by grants from Sigrid Juselius Foundation and Finnish Cancer Organizations to P.L.

\section{REFERENCES}

1. Pollard, T. D. and Borisy, G. G. (2003). Cellular motility driven by assembly and disassembly of actin filaments. Cell Feb 21;112(4):453-65.

2. Chhabra, E. S. and Higgs, H. N. (2007). The many faces of actin: matching assembly factors with cellular structures. Nat Cell Biol. Oct;9(10):1110-21.

3. Goode, B. L., Drubin, D. G. and Lappalainen, P. (1998). Regulation of the cortical actin cytoskeleton in budding yeast by twinfilin, a ubiquitous actin monomersequestering protein. J. Cell. Biol. Aug 10;142(3):723-33.

4. Wahlström, G., Vartiainen, M., Yamamoto, L., Mattila, P. K., Lappalainen, P. and Heino, T. I. (2001). Twinfilin is required for actin-dependent developmental processes in Drosophila. J. Cell Biol. Nov 26;155(5):787-96.

5. Pelkmans, L., Fava, E., Grabner, H., Hannus, M., Habermann, B., Krausz, E. and Zerial, M. (2005). Genome-wide analysis of human kinases in clathrin- and caveolae/raft-mediated endocytosis. Nature. Jul 7;436(7047):78-86.

6. Helfer, E., Nevalainen, E. M., Naumanen, P., Romero, S., Didry, D., Pantaloni, D., Lappalainen, P. and Carlier, M. F. (2006). Mammalian twinfilin sequesters ADP-Gactin and caps filament barbed ends: implications on motility. EMBO J Mar 22;25(6):1184-95.

7. Iwasa, J. H. and Mullins, R. D. (2007). Spatial and temporal relationships between actin-filament nucleation, capping, and disassembly. Curr. Biol. Mar 6;17(5):395-406.

8. Yamada, S., Uchimura, E., Ueda, T., Nomura, T., Fujita, S., Matsumoto, K., Funeriu, D. P., Miyake, M. and Miyake, J. (2007). Identification of twinfilin-2 as a factor involved in neurite outgrowth by RNAi-based screen. Biochem Biophys Res Commun. Noy 30;363(4):926-30.

9. Ojala, P. J., Paavilainen, V. O., Vartiainen, M. K., Tuma, R., Weeds, A. G. and Lappalainen, P. (2002). The two ADF-H domains of twinfilin play functionally distinct roles in interactions with actin monomers. Mol Biol Cell. Nov;13(11):3811-21. 
10. Palmgren, S., Ojala, P. J., Wear, M. A., Cooper, J. A. and Lappalainen, P. (2001). Interactions with PIP2, ADP-actin monomers, and capping protein regulate the activity and localization of yeast twinfilin. J. Cell Biol. Oct 15;155(2):251-60.

11. Vartiainen, M. K., Sarkkinen, E. M., Matilainen, T., Salminen, M. and Lappalainen, P. (2003). Mammals have two twinfilin isoforms whose subcellular localizations and tissue distributions are differentially regulated. J. Biol. Chem. Sep 5;278(36):34347-55.

12. Falck, S., Paavilainen, V. O., Wear, M. A., Grossman, J. G., Cooper, J. A. and Lappalainen, P. (2004). Biological role and structural mechanism of twinfilin-capping protein interaction. EMBO J. Aug 4;23(15):3010-9.

13. Moseley, J. B., Okada, K., Balcer, H. I., Kovar, D. R., Pollard, T. D. and Goode, B. L. (2006). Twinfilin is an actin-filament-severing protein and promotes rapid turnover of actin structures in vivo. J. Cell Sci. Apr 15;119(Pt 8):1547-57.

14. Palmgren, S., Vartiainen, M. and Lappalainen, P. (2002). Twinfilin, a molecular mailman for actin monomers. J. Cell Sci. Mar 1;115(Pt 5):881-6.

15. Lappalainen, P., Kessels, M. M., Cope, M. J. and Drubin, D. G. (1998). The ADF homology (ADF-H) domain: a highly exploited actin-binding module. Mol. Biol. Cell Aug;9(8):1951-9.

16. Paavilainen, V. O., Hellman, M., Helfer, E., Bovellan, M., Annila, A., Carlier, M. F., Permi P. and Lappalainen P. (2007). Structural basis and evolutionary origin of actin filament capping by twinfilin. Proc Natl Acad Sci U S A. Feb 27;104(9):3113-8

17. Vartiainen, M., Ojala, P. J., Auvinen, P., Peränen, J. and Lappalainen, P. (2000). Mouse A6/twinfilin is an actin monomer-binding protein that localizes to the regions of rapid actin dynamics. Mol. Cell Biol. Mar;20(5):1772-83.

18. Peränen, J., Rikkonen, M., Hyvönen, M. and Kääriäinen, L. (1996). T7 vectors with modified T7lac promoter for expression of proteins in Escherichia coli. Anal. Biochem. May 1;236(2):371-3.

19. Pardee, J.D. and Spudich, J.A. (1982). Purification of muscle actin. Methods Enzymol. 85 Pt B:164-81.

20. Detmers, P., Weber, A., Elzinga, M. and Stephens, R.E. (1981). 7-Chloro-4nitrobenzeno-2-oxa-1,3-diazole actin as a probe for actin polymerization. J. Biol. Chem. Jan 10;256(1):99-105.

21. Weeds, A. G., Harris, H., Gratzer, W. and Gooch, J. (1986). Interactions of pig plasma gelsolin with G-actin. Eur. J. Biochem. Nov 17;161(1):77-84.

22. Egile, C., Loisel, T. P., Laurent, V., Li, R., Pantaloni, D., Sansonetti, P. J. and Carlier, M. F. (1999). Activation of the CDC42 effector N-WASP by the Shigella flexneri IcsA protein promotes actin nucleation by Arp2/3 complex and bacterial actinbased motility. J Cell Biol Sep 20;146(6):1319-32. 
23. Cooper, J. A., Walker, S. B. and Pollard, T.D. (1983). Pyrene actin: documentation of the validity of a sensitive assay for actin polymerization. J Muscle Res Cell Motil. Apr;4(2):253-62.

24. Casella, J. F., Maack, D. J., and Lin, S. (1986). Purification and initial characterization of a protein from skeletal muscle that caps the barbed ends of actin filaments. J Biol Chem Aug 15;261(23):10915-21.

25. Pollard, T. D. (1986). Rate constants for the reactions of ATP- and ADP-actin with the ends of actin filaments. J Cell Biol. Dec;103(6 Pt 2):2747-54

26. Maciver, S. K. and Weeds, A. G. (1994). Actophorin preferentially binds monomeric ADP-actin over ATP-bound actin: consequences for cell locomotion. FEBS Lett. Jun 27;347(2-3):251-6.

27. Carlier, M. F., Laurent, V., Santolini, J., Melki, R., Didry, D., Xia, G. X., Hong, Y., Chua, N. H. and Pantaloni, D. (1997). Actin depolymerizing factor (ADF/cofilin) enhances the rate of filament turnover: implication in actin-based motility. J. Cell Biol. Mar 24;136(6):1307-22.

28. Blanchoin, L., and Pollard, T. D. (1998). Interaction of actin monomers with Acanthamoeba actophorin (ADF/cofilin) and profilin. J. Biol. Chem Sep 25;273(39):25106-11.

29. McKim, K. S., Matheson, C., Marra, M. A., Wakarchuk, M. F. and Baillie, D. L. (1994). The Caenorhabditis elegans unc-60 gene encodes proteins homologous to a family of actin binding proteins. Mol. Gen. Genet. Feb;242(3):346-57.

30. Ono, S., Bailli, D. L. and Bnian, G. M. (1999). UNC-60B, an ADF/cofilin family protein, is required for proper assembly of actin into myofibrils in Caenorhabditis elegans body wall muscle. J Cell Biol. May 3;145(3):491-502.

31. Ono S. (2003). Regulation of actin filament dynamics by actin depolymerizing factor/cofilin and actin-interacting protein 1: new blades for twisted filaments. Biochemistry. Nov 25;42(46):13363-70.

32. Ono, S., Minami, N., Abe H. and Obinata, T. (1994). Characterization of a novel cofilin isoform that is predominantly expressed in mammalian skeletal muscle. J. Biol. Chem. May 27;269(21):15280-6.

33. Vartiainen, M. K., Mustonen, T., Mattila, P. K., Ojala, P. J., Thesleff, I., Partanen, J. and Lappalainen, P. (2002). The three mouse actin-depolymerizing factor/cofilins evolved to fulfil cell-type-specific requirements for actin dynamics. Mol Biol Cell. Jan;13(1):183-94.

34. Bertling, E., Hotulainen, P., Mattila, P. K., Matilainen, T., Salminen, M. and Lappalainen, P. (2004). Cyclase-associated-protein 1 promotes cofilin-induced actin dynamics in mammalian nonmuscle cells. Mol. Biol. Cell. May;15(5):2324-34. 
35. Beggs, A. H., Byers, T. J., Knoll, J. H., Boyce, F. M., Burns, G. A. and Kunkel, L. M. (1992). Cloning and characterization of two human skeletal muscle alpha-actinin genes located on chromosomes 1 and 11. J Biol Chem. May 5;267(13):9281-8.

36. Honda, K., Yamada, T., Endo, R., Ino, Y., Gotoh, M., Tsuda, H., Yamada, Y., Chiba, H. and Hirohashi, S. (1998). Actinin-4, a novel actin-bundling protein associated with cell motility and cancer invasion. J. Cell Biol. Mar 23;140(6):1383-93.

37. Tang, H., Heeley, T., Morlec, R. and Hubbard, S. J. (2007). Characterising alternate splicing and tissue specific expression in the chicken from ESTs. Cytogenet Genome Res. 117(1-4):268-77.

38. Paavilainen, V. O., Merckel, M. C., Falck, S., Ojala, P. J., Pohl, E., Wilmanns, M. and Lappalainen, P. (2002). Structural conservation between the actin monomerbinding sites of twinfilin and actin-depolymerizing factor (ADF)/cofilin. J Biol Chem. Nov 8;277(45):43089-95.

39. Chereau, D., Boczkowska, M., Skwarek-Maruszewska, A., Fujiwara, I., Hayes, D.B., Rebowski, G., Lappalainen, P., Pollard, T.D. and Dominguez, R. (2008). Leiomodin is an actin filament nucleator in muscle cells. Science. Apr 11;320(5873):239-43. 


\section{FIGURE LEGENDS}

FIGURE 1. Generation of two isoforms from the twinfilin-2 gene. A) The organization of the twinfilin-2 gene. In contrast to twinfilin-2a, which contains 9 exons, the first exon is omitted from the twinfilin-2b mRNA and the translation begins from exon 2 (marked $2 \mathrm{~b}$ ), which is elongated as compared to the corresponding exon in twinfilin-2a. B) Alignment of mouse twinfilin-2a (Twf-2a) and twinfilin-2b (Twfb) amino acid sequences. The two sequences differ at the very first $6 / 8$ amino terminal residues. The GenBank accession numbers of mouse twinfilins are AY267188 (twinfilin-1), AY267189 (twinfilin-2a) and AK002699.1 (twinfilin-2b).

FIGURE 2. Expression profiles of the three mouse twinfilin isoforms A) A nonquantitative RT-PCR analysis of the expression of different twinfilin and GAPDH mRNAs in selected mouse tissues. B) Quantitative PCR (Q-PCR) analysis from mRNAs isolated from indicated mouse tissues. The PCR primers used are listed in Table 1. GAPDH amplification was used as a control. Twinfilin-2b is the most abundant isoform in heart and skeletal muscles, whereas twinfilin-2a and twinfilin-1 are expressed widely in non-muscle tissues. Twinfilin-2a is the predominant isoform in spleen and twinfilin-1 in lung, kidney, liver, and brain.

FIGURE 3. Interactions of mouse twinfilins and the isolated ADF-H domains of twinfilin-2 with actin monomers. Increase in the fluorescence of NBD-labelled ATPG-actin (open circles) or ADP-G-actin (closed circles) was measured at different concentrations of mouse twinfilin isoforms and the isolated domains of twinfilin-2a and $-2 b$. The experiment was carried out with $0.2 \mu \mathrm{M}$ actin under physiological ionic conditions. Symbols indicate data and the solid lines are fitted binding curves for a complex with 1:1 stoichiometry. A) Full-length twinfilin-1, B) full-length twinfilin-2a, C) full-length twinfilin-2b, D) N-terminal ADF-H domain of twinfilin-2a, E) Nterminal ADE-H domain of twinfilin-2b, and F) C-terminal ADF-H domain of twinfilin-2a/b.

FIGURE 4. All mouse twinfilin isoforms cap actin filament barbed ends. In a pyrene-actin polymerization assay, barbed-end growth (filled circles) and pointed-end 
growth (open circles) were initiated by using spectrin-actin seeds and gelsolin-actin seeds, respectively. $2,5 \mu \mathrm{M}$ of $10 \%$ pyrenyl-labelled G-actin was used and the twinfilin concentrations were as indicated on the $\mathrm{x}$-axis. The initial polymerization rates were normalized to the value of 1 measured in the absence of twinfilin. Similarly to twinfilin-1, the inhibition of barbed-end polymerization was stronger at low concentrations of twinfilin-2a and twinfilin-2b than expected from monomer sequestering, indicating barbed-end capping. The effects of twinfilin isoforms at pointed ends are accounted for sequestration of actin in a 1:1 complex. The obtained $\mathrm{K}_{\mathrm{T}}$ (ATP-G-actin sequestration) and $\mathrm{K}_{\mathrm{F}}$ values (barbed-end capping) are depicted in the figure.

\section{FIGURE 5. All mouse twinfilin isoforms interact with heterodimeric capping} protein. Binding of twinfilin isoforms to capping protein was studied by a native gel electrophoresis assay. Mouse full-length twinfilins and a mutant twinfilin-1 lacking the capping protein binding site were loaded on a gel either separately or as a mixture with mouse $\alpha 1 \beta 2$-capping protein. The concentration of twinfilins was $2 \mu \mathrm{M}$ and the concentration of capping protein was $4 \mu \mathrm{M}$. Lane 1 shows the mobility of capping protein alone, lanes 2, 4, 6 and 8 show the mobilities of wild-type twinfilin-1, mutant twinfilin-1, twinfilin-2a and twinfilin-2b, respectively. When mixed with capping protein, the twinfilin-1, twinfilin-2a and twinfilin-2b disappear from their original migration position and a new band corresponding to the twinfilin/capping protein complex appears above the original migration positions of the proteins (lanes 3, 7 and 9). In contrast, the electrophoretic mobility of the mutant twinfilin-1 lacking the capping protein binding site (see ref. 12) is not affected by the presence of capping protein (lane 5).

FIGURE 6. Localization of the twinfilin isoforms in heart muscle cells. A) Subcellular localization of endogenous twinfilins in cultured neonatal rat cardiomyocytes. An antibody recognizing all three twinfilin isoforms showed punctuate cytoplasmic localization and also revealed enrichment of twinfilins to myofibrils in a subset of cells. B) In cells expressing myc-tagged twinfilins, twinfilin1 and twinfilin-2b displayed mainly punctuate cytoplasmic localization, but were also enriched in myofibrils (arrowheads in the insets). Twinfilin-2b displayed punctuate 
cytoplasmic localization with some enrichment in the regions between the myofibrils (arrows in the insets). Bars, $10 \mu \mathrm{m}$.

\section{TABLES}

TABLE 1. Sequences of the oligonucleotides used in Q-PCR

\begin{tabular}{|l|l|}
\hline Primer name & Sequence \\
\hline ES110 & TAC CGC ACC CTG CGC CGG A \\
\hline ES121 & TCT GTA TTT CCC GTT TCT GGC TCG G \\
\hline ES122 & CCA GGA CCA AGA GGA GAA CTC C \\
\hline ES124 & CTT TGA TAA GTC GGA TGG AGC CAG C \\
\hline ES125 & CAC CAG CAG ACC CAA ACT CTT CCC T \\
\hline ES126 & GCA AAG TGG AGA TTG TTG CCA T \\
\hline ES127 & CCT TGA CTG TGC CGT TGA ATT T \\
\hline
\end{tabular}




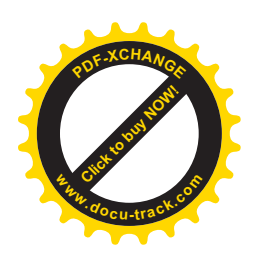

Figure 1.

Nevalainen $\mathrm{EM}$ et al

A.

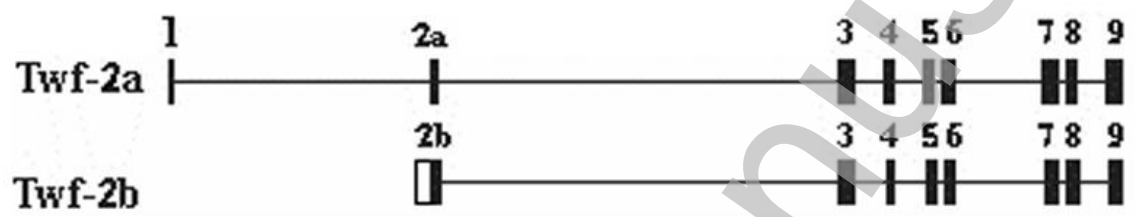

B.

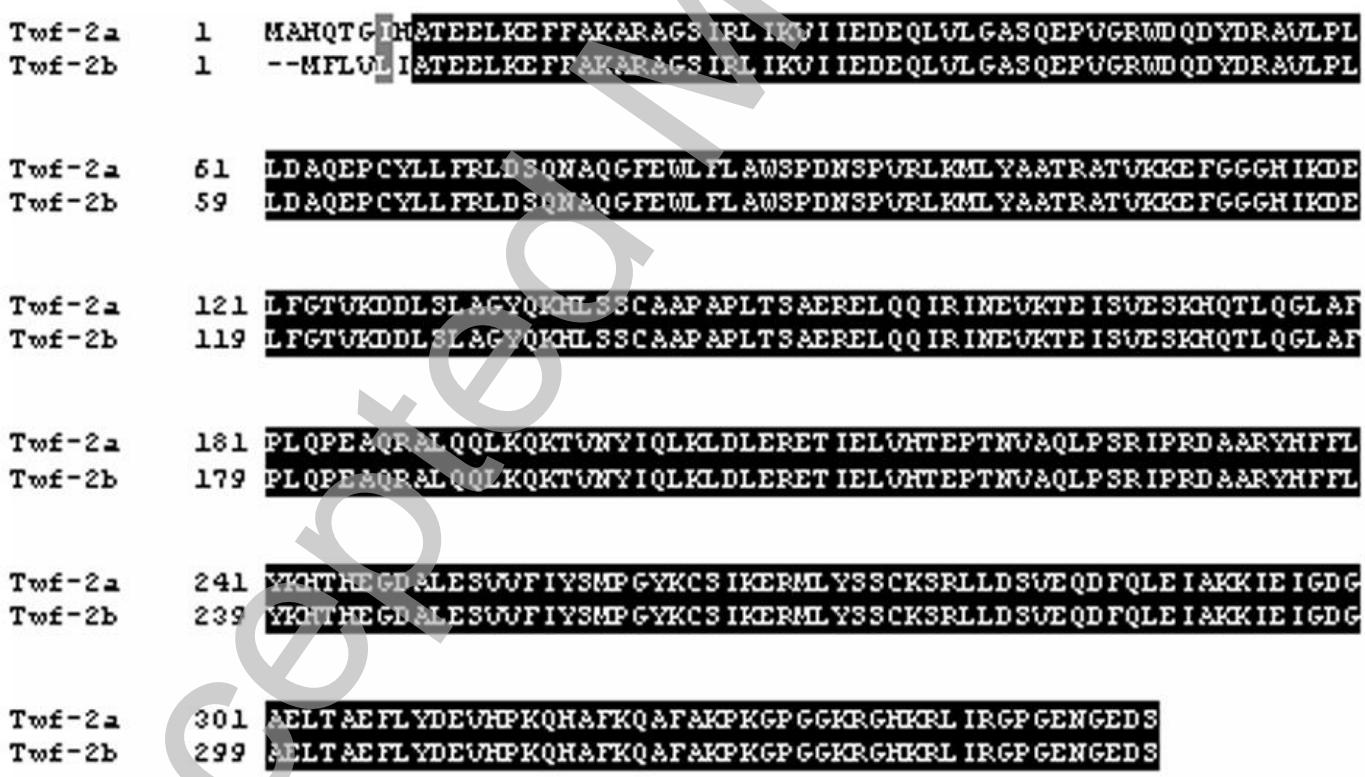

Licenced copy. Copying is not permitted, except with prior permission and as allowed by law.

(C) 2008 The Authors Journal compilation (C) 2008 Biochemical Society 


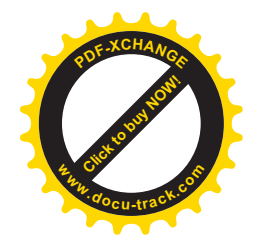

Figure 2.

A.

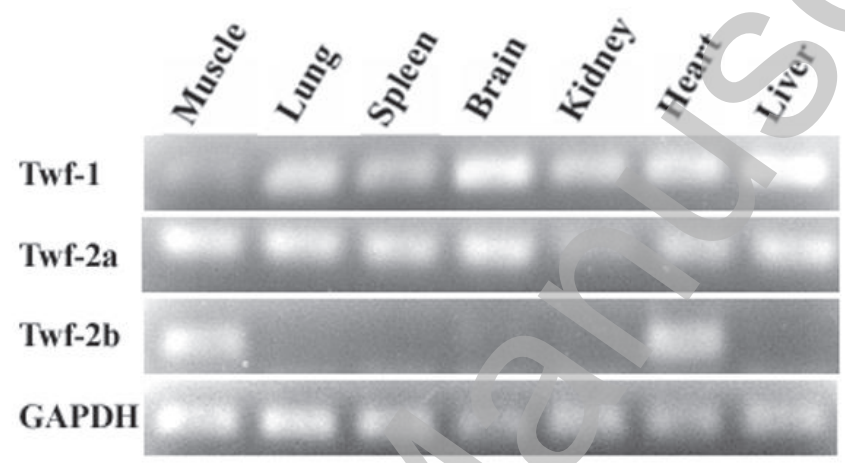

B.

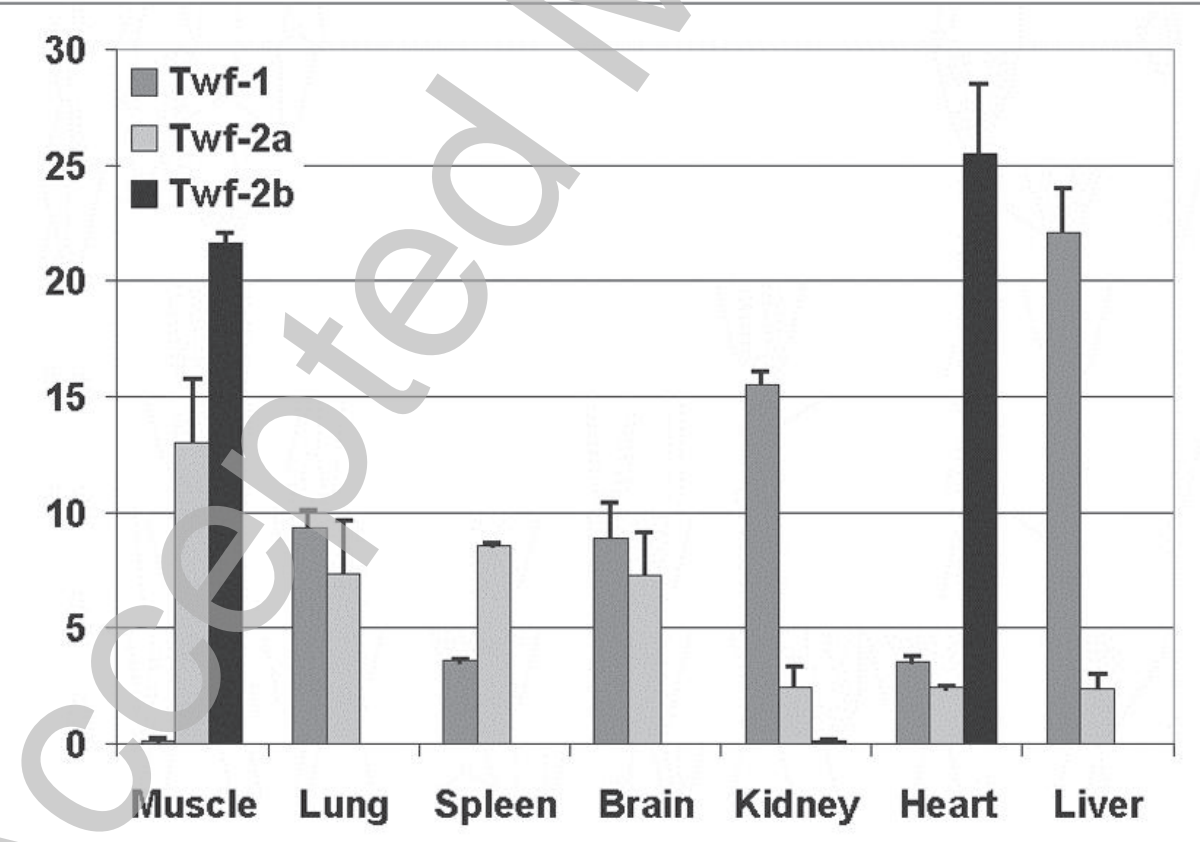


Figure 3

A.

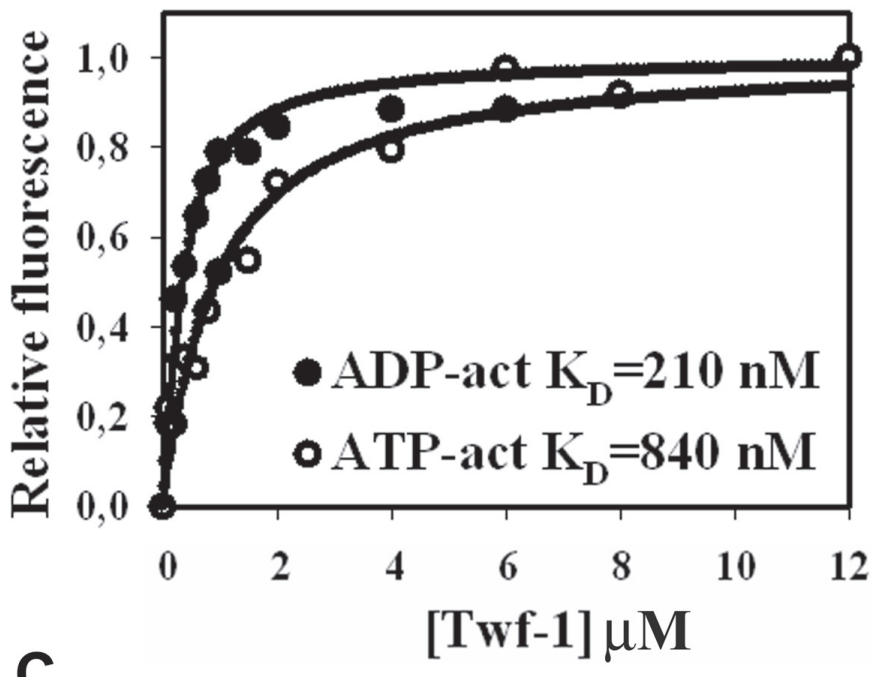

C.

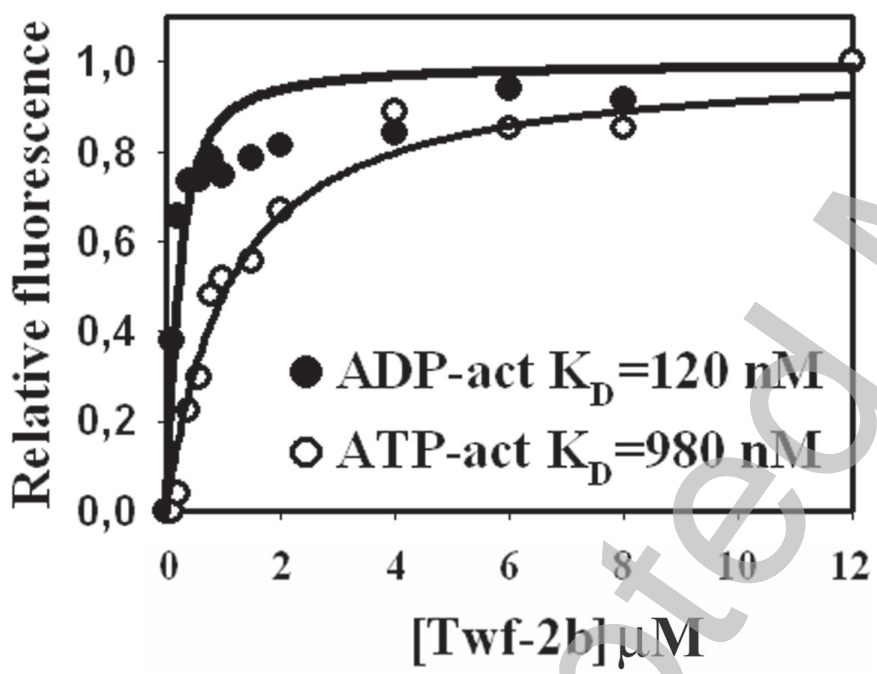

E.

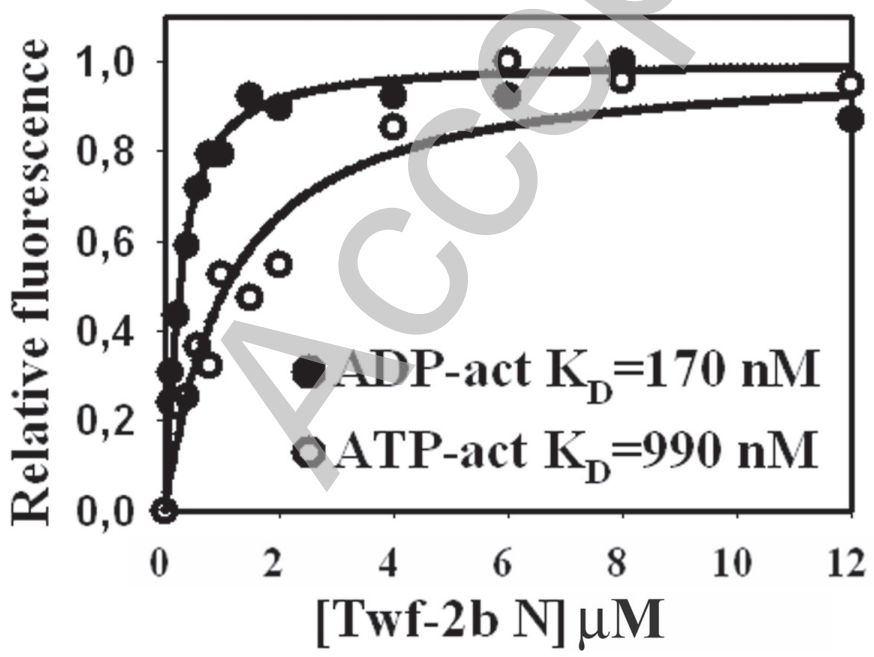

Nevalainen EM et al.

B.

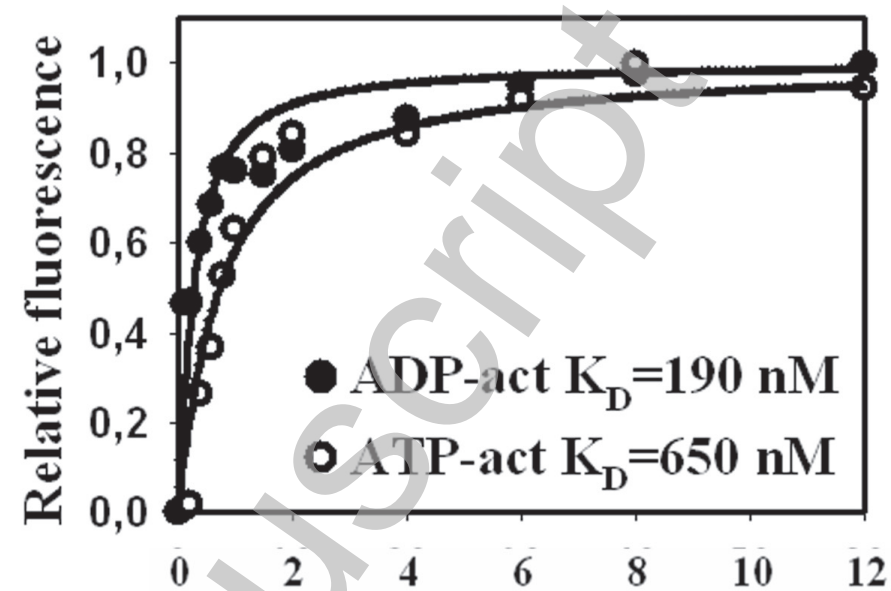

[Twf-2a] $\mu \mathrm{M}$

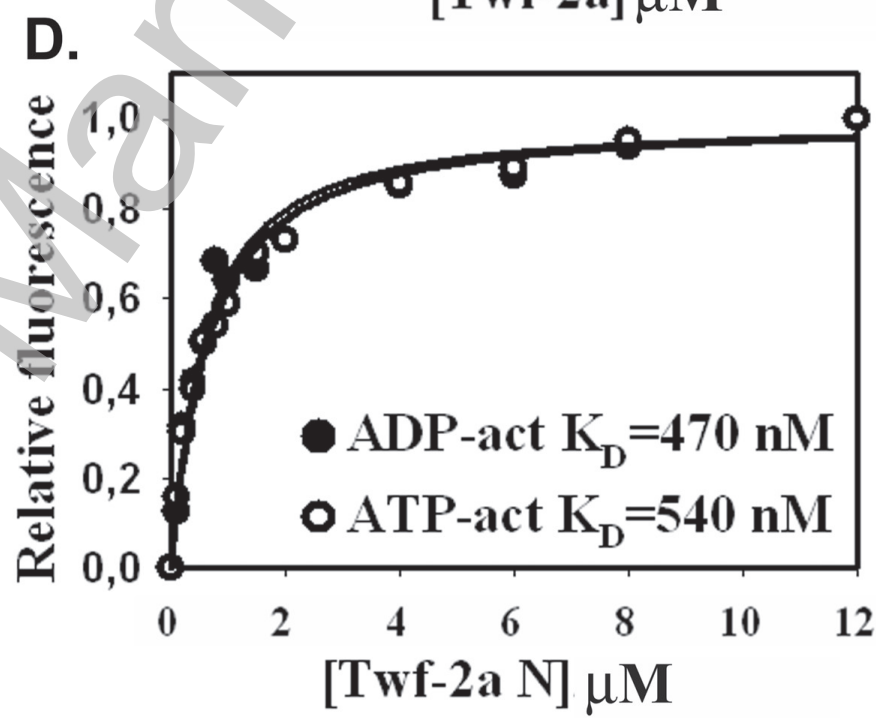

F.

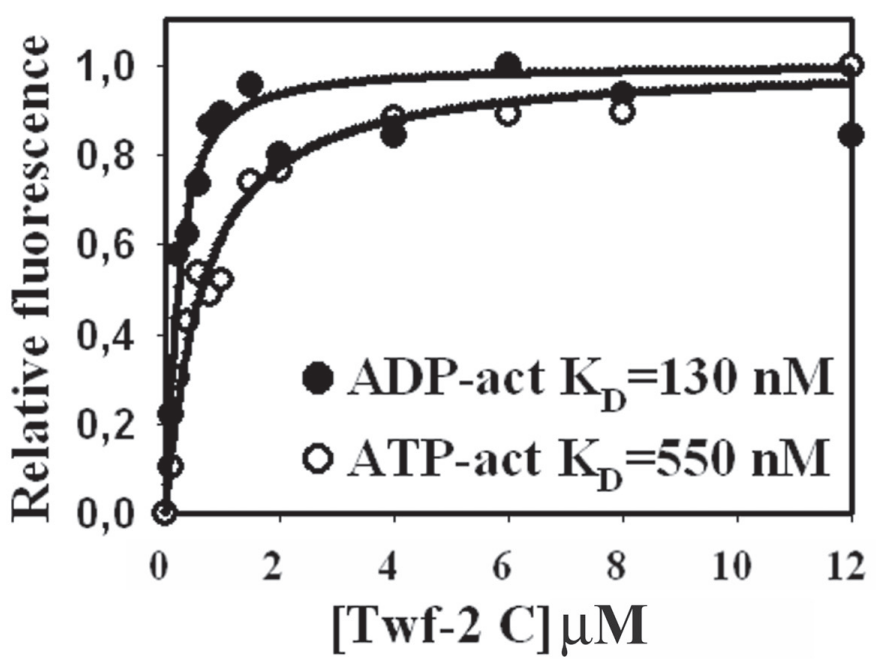




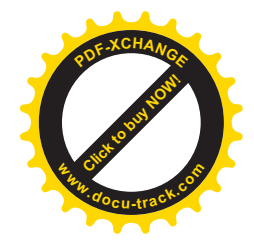

Figure 4

Nevalainen EM et al
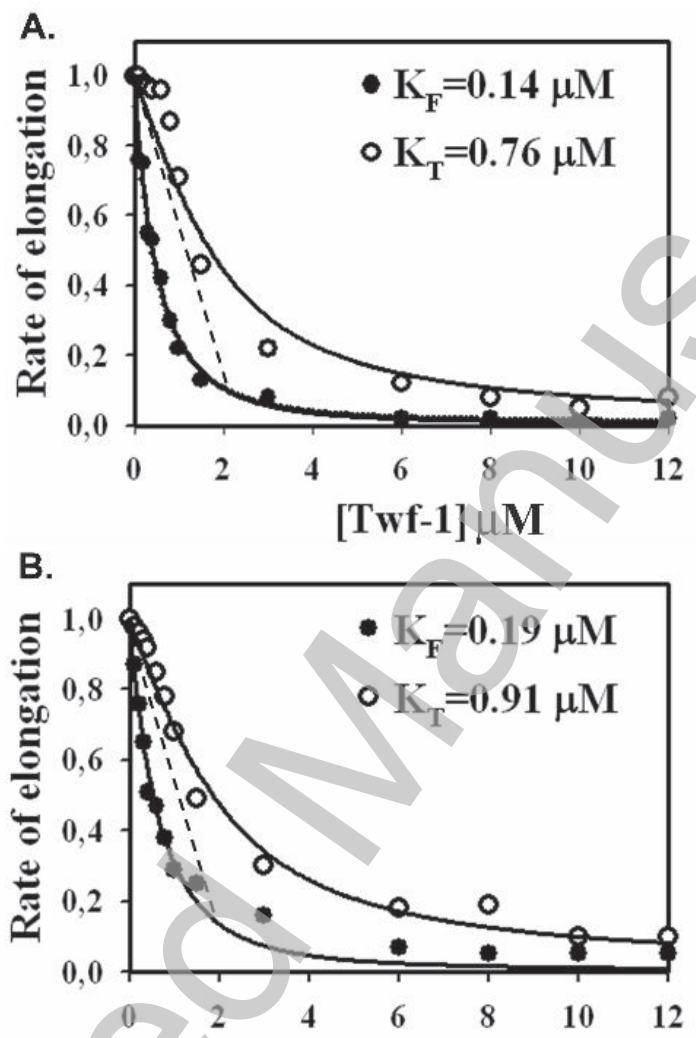

[Twf-2a] $\mu \mathrm{M}$

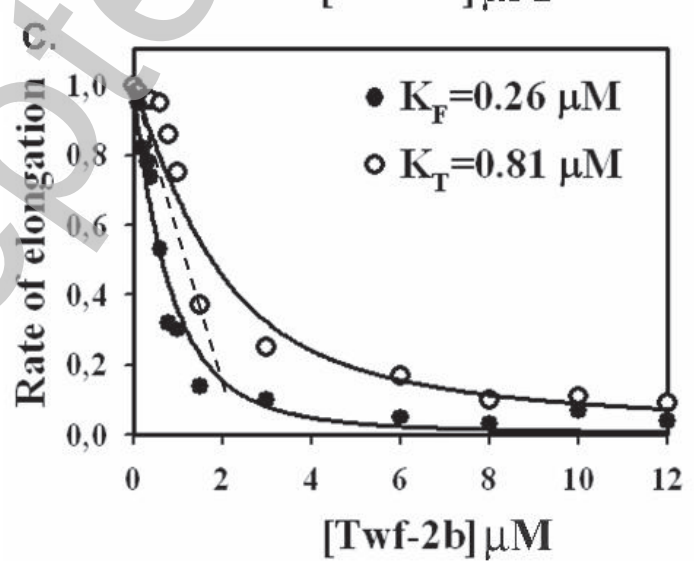

Licenced copy. Copying is not permitted, except with prior permission and as allowed by law. (C) 2008 The Authors Journal compilation (C) 2008 Biochemical Society 


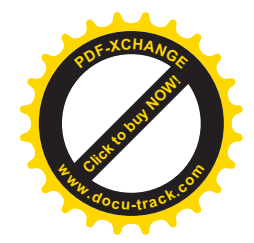

Figure 5

\section{Nevalainen EM et al}

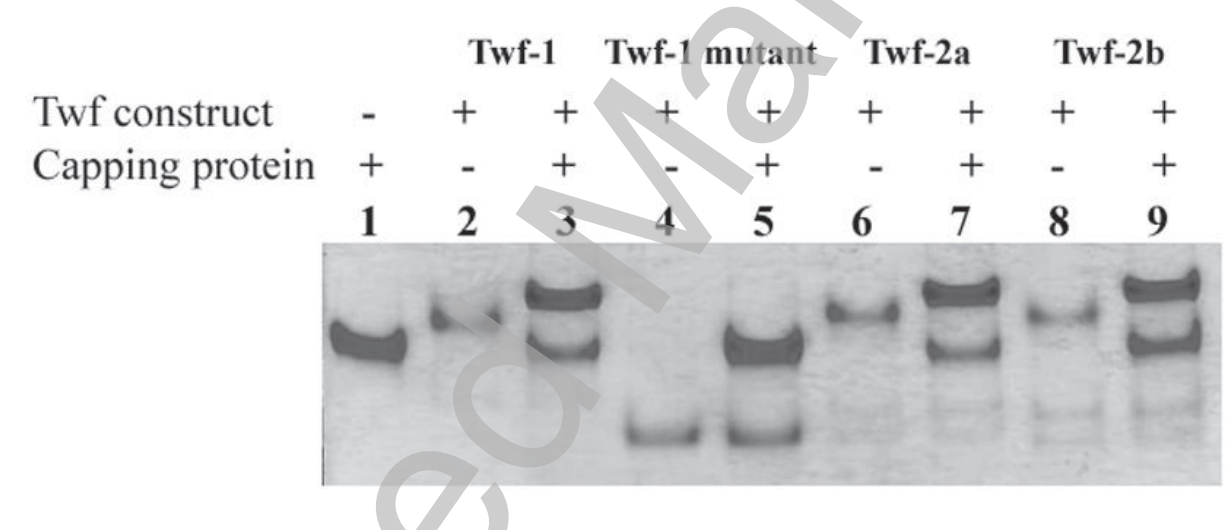




\section{Figure 6}

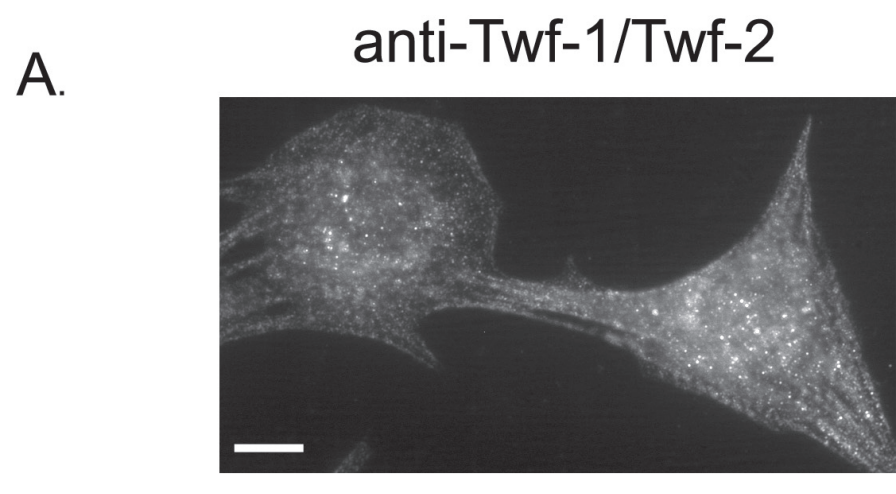

anti-Twf-1/Twf-2

B.

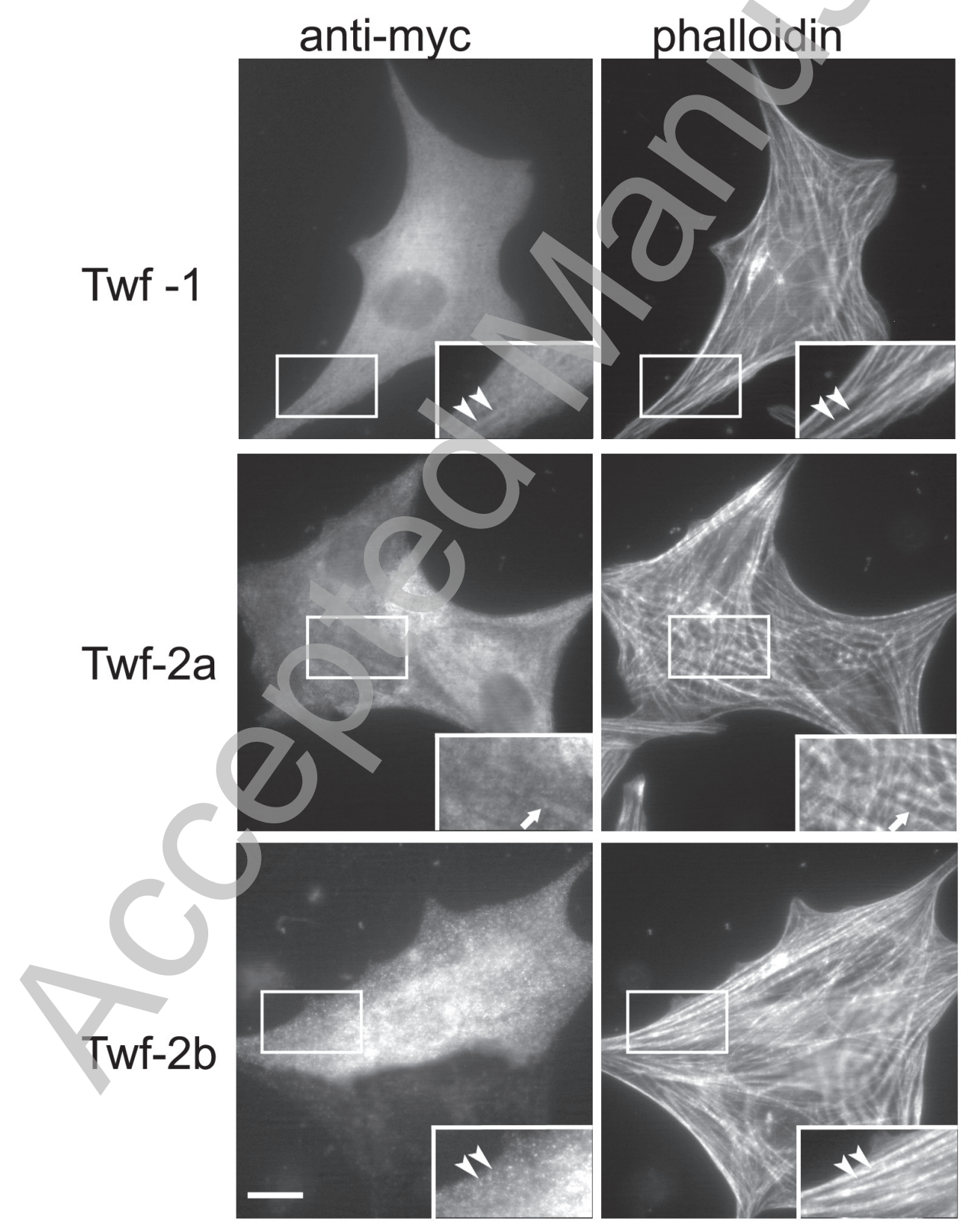

phalloidin

Nevalainen EM et al.

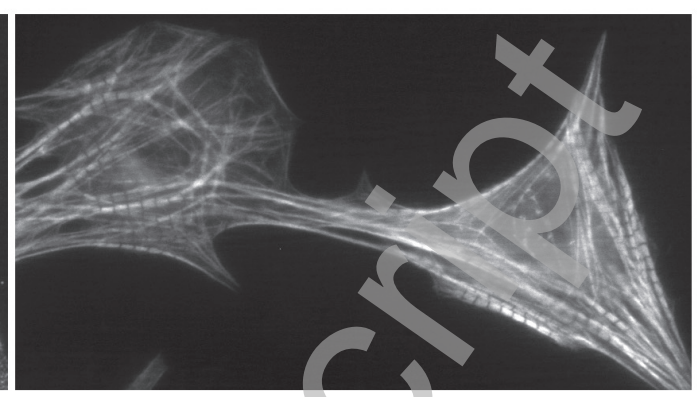

